\section{E-LOGOS}

ELECTRONIC JOURNAL FOR PHILOSOPHY ISSN 1211-0442

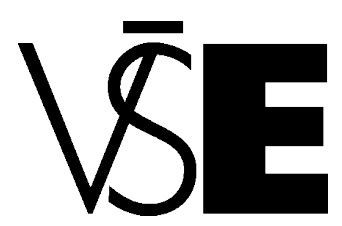

University of Economics

Prague

\title{
K některým aspektům antického pojetí dějin
}

Miroslav Vlček

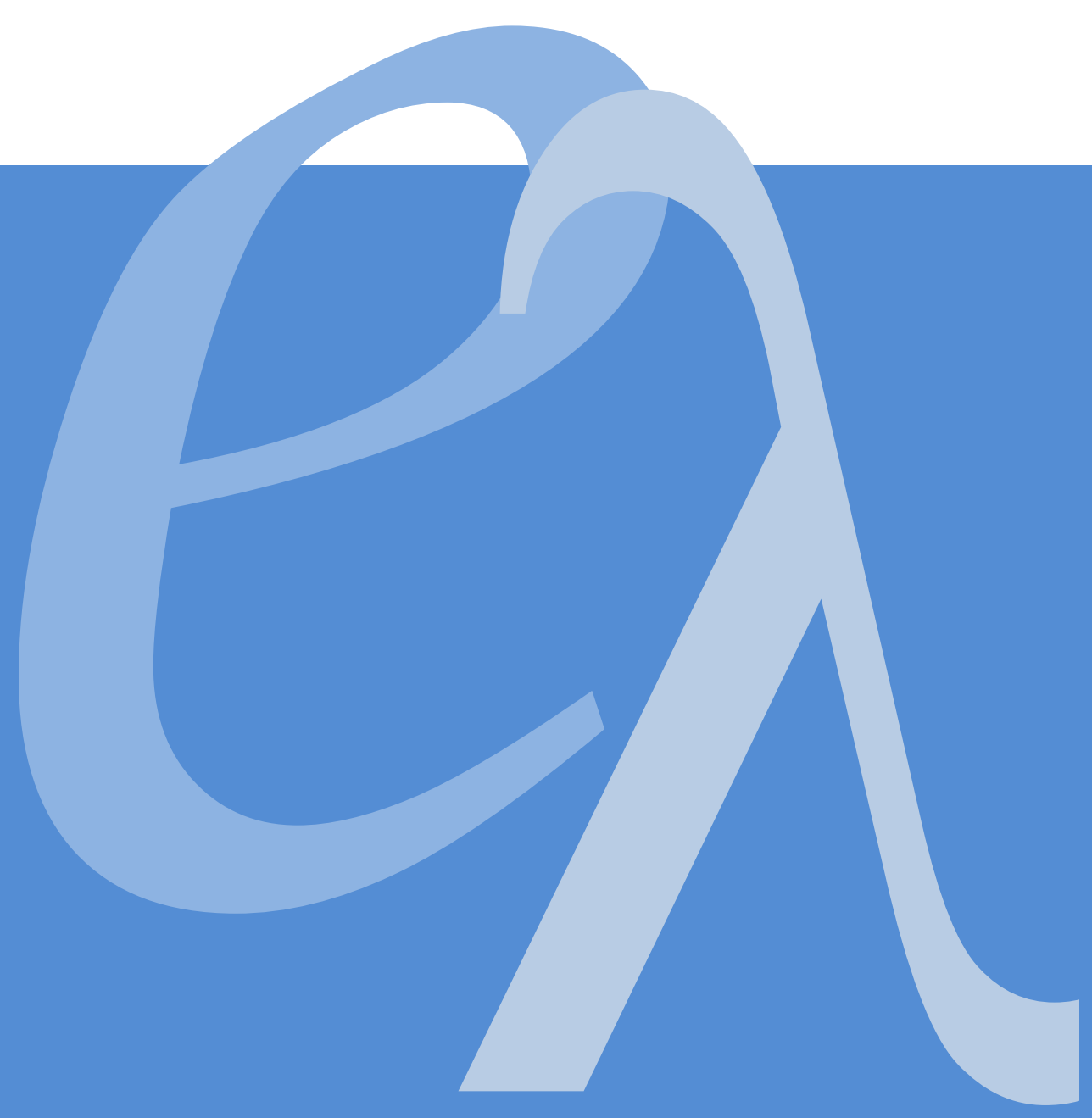




\begin{abstract}
Presented study tries to map most important conceptions of history in Antics. It's already found in Greek mythology, in Hesiod, who comes as the first with concept of continually descending ages of humanity. This conception can be found later in Plato, especially in his conception of constitutions. It can be found in Poseidonius of Apameia, philosopher of the second phase of stoicism, who later influenced roman spirituality which perceives history as descent.
\end{abstract}

\begin{abstract}
Abstrakt
Předkládaná studie se pokouší zmapovat rozhodující mezníky antického pojetí dějin. Kořeny tohoto nacházíme již v řecké mythologii, u Hesioda, jenž přichází jako první s tzv. koncepcí postupně upadajících věků lidstva. Tato koncepce je lokalisovatelná posléze u Platóna, zejména pak $\mathrm{v}$ jeho koncepce ústav. Najdeme ji u vrcholného představitele druhé etapy stoicismu, Poseidonia z Apameie, který následně ovlivní římskou spiritualitu s jejím vnímáním dějin coby úpadku. Vedle této linie pak studie sleduje ještě linii tzv. cyklického pojetí dějin, která má zřejmě kořeny v mythologické tradici a je následně zpracována presokratovskou filosofií (Herakleitos z Efesu), najdeme ji u Platóna, ale zejména pak u „pilíře“ stoy Chrysippa ze Soloi, Poseidonia a následně se pak stane součástí římského myšlení. Do jakéhosi kontrapunktu pak studie, alespoň v náznaku, staví tzv. lineární pojetí dějin vlastní židovsko-křestáanské tradici a vrcholně zpracované Augustinem Aureliem.
\end{abstract}




\section{K NĚKTERÝM ASPEKTŮM ANTICKÉHO POJETÍ DĚJIN ${ }^{1}$}

Inspirací pro sepsání následující studie se mi stala kniha K. R. Poppera Otevřená společnost a její nepřátelé, kde autor v prvním dílu pojednává o Platónovi coby představiteli tzv. historicismu.

Popperovy závěry jsou na první pohled překvapivé, Platón je myslitelem věčného nehybného „světa“ pravých jsoucen (TA ONTA) připouštějící pohyb/dění a tedy dějinnost a tedy časnost pouze $\mathrm{v}$ derivovaném světě jsoucen měnících se (TA GIGNOMENA).

Podíváme-li se, tak jak to činí Popper, na jeho velkolepou Ústavu sklenující v jistém smyslu celou jeho filosofii druhého období, pak máme před sebou koncept, který vrhá na jeho filosofii zvláštní pohled či otevírá nové otázky (což reflexe Platónovy filosofie ostatně vyvolávala a vyvolává vždy²).

Skrze Ústavu je možné nahlédnout, jak je to s Platónovou koncepcí dějin resp. $\mathrm{s}$ jeho vnímáním času. Vycházíme předběžně z toho, že Platón navazuje a v jistém smyslu spojuje dva mytologicko-filosofické koncepty dosavadní řecké tradice, totiž hesiodovskou představu dějinného sestupu věků a zároveň cyklické vnímání času/dění. Platón je prvním, který explicite spojil oba koncepty. Popper hovoří o Platónově víře v možnost zastavit postupný úpadek proplétající se coby červená nit dějinami. Právě mravním zdokonalením, které je přímým důsledkem dokonalého poznání, může člověk zvrátit dějinný úděl. ${ }^{3}$

Je otázkou, zda-li vise ideálního státu není spíše důsledkem jiné (ne)řecké vise, víry ve věčný návrat téhož.

Klademe si za úkol shrnout to, co Platónově syntéze předcházelo, tj. předsokratovskou mythologicko filosofickou tradici, jež oba momenty Platónovy dějinné koncepce přináší.

Velmi podobnou se nám pak jeví to, co kol přelomu letopočtu vytváří římská spiritualita, která ovšem nemá jediného protagonistu, jde spíše o společné dílo

1 Antickou filosofií rozumíme období počínající 6. stol. př.n.l. A končící 6. stol. n.l. Toto dvanáctisetleté období je rozdělitelné různým způsobem. Pro nás možná produktivní je období před Kristem, období prvních dvou etap antického filosofování, kdy rozdělujícím mezníkem je Aristotelova smrt, kdy antice vládne výhradně řecko-římská spiritualita, a období po Kristu, které je také složeno z dvou etap, přičemž předělem je vystoupení Plotinovo (či Origenovo), kdy na dějinou scénu přichází křestanství. Souhrně je tedy antická filosofická tradice tvořena čtyřmi etapami. Pokud jsme hovořili o jisté signifikantnosti rozdělení antického filosofování před a po Kristovi, pak jsme měli na mysli naše téma a právě rozdílné chápání dějin: jinak rozumí dějinám tradice předchozí, jinak potom židovskokřest́anská tradice.

2 Viz známé konstatování Wittheada: „celá západní filosofie jsou poznámky k Platónovi.“

3 V tom Popper spatřuje jakési prolomení historicismu, který je definován nemožností jakkoli ovlivnit dějiny zcela svázané neměnnými zákonitostmi. Podle autora lze v Platónově koncepci najít rovněž aspekty tzv. sociálního inženýrství, tedy přesvědčení, že člověk je pánem svého osudu a že tedy může měnit své dějiny. 
stoicismu a římské poesie přicházející se specifickou interpretací řecko-římské mythologie, jejímiž hegemony jsou v tomto př́ipadě Ovidius a Vergilius. I pro tradici mezi těmito "syntézami“, tj. pro filosofii hellenistickou pro nás representovanou zejména stoicismem, zčásti platí toto spojení. Prokazatelné je cyklické pojetí, u Poseidonia najdeme také představu zlatého věku. Pro římskou stou 1. stol.př.n.l. bude koncept věků zřejmě konstantou.

Naši studii proto rozdělíme do čtyř oddílů. Dodatečný oddíl pátý bude jen jakési připomenutí tradice zásadně nové, jakýsi kontrapunkt k probíranému.

\section{Předplatónská tradice}

Jak jsme naznačili v úvodu, $\mathrm{z}$ hlediska naší tématizace předsokratovská tradice přichází s oběma sledovanými př́stupy. ${ }^{4}$

\section{a) Hesiodovský koncept}

Hesiodos přichází ve svém pojednání Práce a dni (ERGA KAI HÉMERAI) s představou tzv. „věkư“ lidstva, kdy dějiny jsou chápány jako postupná střída pěti věků lidstva od tzv. věku zlatého až $\mathrm{k}$ věku současnému, tj. železnému. Hesiodos, rapsód 7. stol. př.n.l., pravděpodobně zhodnocuje představy předešlé, nezachycené ale skrze písemné památky. Je nutno si uvědomit, že Hesiodos přichází po tzv. temných staletích, mezidobí mezi zánikem skvělé mykénské civilizace, obdobím opěvovaném homérskými eposy. To je asi důvod zvláštní Hesiodovy optiky, po skvělém "zlatém“ období Homérových heroů přichází úpadek. Idealizace toho, co bylo, je rysem typickým na všech úrovních našeho života, včetně našeho osobního. Zřejmě tuto filosofii vzpomínky promítá Hesiodos do své dějinné koncepce. Tato se sama o sobě jeví jako lineární, tj. postupující v jedné (nekonečné) sestupné linii. Připomeňme si nyní samotného Hesioda.

$$
\begin{gathered}
\text { "Ještě jinou zkazku ti budu vyprávět, chceš-li, } \\
\text { pěkně a důmyslně, a ty si ji do srdce ulož: }
\end{gathered}
$$

kterak bozi i smrtelní lidé si žívali stejně.

Nejprve zlatý věk a zlaté smrtelné plémě stvořili nesmrtelní, co bydlí volympských sídlech.

Oni žili v ten čas, kdy na nebi kraloval Kronos; nejinak žili než bozi a neměli starostí v srdci, bez práce, bez protivenství a běd; ani starobu vetchou neznali; věčně ruce i nohy majíce stejné, 
z hojnosti všeho se těšili, zlo se jich nedotklo žádné; mřeli tak lehko, jako když usne; na dosah měli všecko dobré a sklizeň jim dávala plodistvá země od sebe sama, a hojnou a bujnou; oni se chutě dělili o dílo v klidu v tom nadbytku všelikých darů, bohati na stáda bravu a milí blaženým bohưm.

Avšak to pokolení že černá pokryla hlína, jsou z nich daimonové dle úradku velkého Dia, pozemští, dobrodějní a strážcové smrtelných lidí; oni dávají pozor, kdo jedná správně či špatně, $v$ oblaku zahaleni a po zemi chodíce všady, blahodární; i tuto čest mají narovno s králi.

Druhé pokolení, už střibrné, o mnoho horší potom stvořili bozi, co bydlí volympských sídlech; ani vzrůst, ani mysl už nemělo jako to zlaté. Století celé své veliké nemluvně, zákrska-syna pečlivá matka si musela krmit a pěstovat doma; ale sotvaže dospěl a dorostl na míru muže, kratičký čas byl živ a nesl za hořem hoře z nerozumu; vždyt' nedovedli svou pýchu a zpupnost zadržet od druha druh, ani nechtěli uctívat bohy, ani na oltářch těm blaženým spalovat žertoy, jak je u lidí slušno a zvykem. A nakonec v hněvu rozenec Kronův Zeus je vyhladil, protože pocty blaženým bohům, jimž patři Olymp, nechtěli vzdávat.

Avšak $i$ toto pokolení když pokryla hlína, dostali od lidí jméno ti blažení podzemní - druzí, ale i tak je provází úcta na věčné časy.

Otec Zeus pak třetí plémě smrtelných lidí, 
bronzové, stříbrnému už nikterak podobné, stvořil, z jasanů, hrozné a obrovité; ti o žalné dílo Áreovo a násilí dbali a nejedli chleba, nýbrž srdce tordé jak ocel měli a zpupné; strach je potkat a strach se dotknout té veliké síly, pádných paži, jež na hrubém trupu od ramen rostly.

Bronzovou měli zbroj a bronzové měli i domy, bronzem pracovali; neb neznali železo černé.

Vlastníma rukama oni se navzájem pobivše sešli do domu zatuchlého a k zimomřivému Hádu beze slávy; $i$ je, ač bývali strašní, si vzala černá smrt a opustili svit jasného slunce.

Avšak $i$ toto pokolení když pokryla hlína, jiné ještě plémě, už čtorté, na žioné zemi stvořil Zeus, syn Kronův, lepši a spravedlivější, héroủ zbožný rod, ty muže, kterým se ř́ká polobozi; tot' prastaré plémě na širé zemi.

Ty ale lítý zahubil boj a krvavá vřava, jedny pod sedmi branami Théb a v Kadmově zemi, když se utkali o brav a o statek po Oidipovi; druhé zas $k$ Tróji přes velký jícen moře is lod'mi přivedla vojna, že Helenu s krásnými pletenci chtěli.

Když potom černá smrt je zahalila a konec, daleko od lidí sídlo a živobytí jim prìrkl otec Zeus, syn Kronưv, až na samém okraji země, daleko od nesmrtelných a jejich králem je Kronos.

Tam oni bydli-žiji a nemají starostí v duši, na výspách blaženosti a při vírech Ókeanových, blaženi héroové, a sklizeň, jež do roka třikrát 
metá, sladkou jako med, jim dává plodistvá země. ${ }^{5}$

Kéž jsem se neoctl já mezi muži pátého věku,

kéž jsem umřel dřív nebo prišel na svět až potom!

Nyní je totiž už železné plémě; to oddechu nezná

od běd a lopot za dne a nemá pokoje v noci,

napořád hynouc, a těžkých strastí jim pridají bozi;

nicméně také jim se ke zlému přmimisi dobré.

Zahubí Zeus i toto smrtelné plémě, vždyt’ děti, sotvaže přijdou na svět, už mají šedivé vlasy.

Otec synům už nebude vhod, ani synové otci, hostiteli se znelíbí host a príteli prítel, rodný bratr už nebude milý, jak bývalo dříve.

Rychle prestanou mit své stárnoucí rodiče v úctě, budou je tupit a dotírat na ně př́krými slovy, krutí! O boží pomstu se nestarajíce; svým starým rodičưm nebudou chtít se odvděčit za vychováni; podle pěstního práva druh druhu vyorátí město.

Nebude ve cti, kdo stojí v slovu, a spravedlivého ani dobrého muže si nebudou vážit; to spíše násilníka a zločince; stud se ztratí, i víra v rukoudáni; ten horší muž bude lepšímu škodit, křivými slovy ho nařkne a ještě př́sahu přidá. Lidem neštastnikưm se na paty pověsí všechněm zlolajná závist, škodolibá a ošklivá v tvárì.

Tehdy už od země širokých cest se k Olympu vznesou, rouchem běloskvoucím si halíce spanilé tělo, do sboru nesmrtelných a samotny nechají lidi

Stud a Spravedlnost; i nezbude smrtelným lidem

${ }^{5}$ De facto věk heroů je jakousi výjimkou v předpokládaném sestupu. Je to Hesiodova vzpomínka na časy řeckých hrdinů od Théb, Troji aj. Ovidius jej již mít nebude. 
nic než bída a žal - a nebude pomoci od zla."6

Tolik básník.

Hesiodovo vyprávění se týká pěti pokolení lidstva. Zlatý věk je spojen s Kronovou vládou, zbylé pak s Diovou. Stvoření člověka je konstatováno. Hesiodos nám nikde ${ }^{7}$ explicite nelíčí proces stvoření člověka, leccos však naznačuje, že i Řekové pracují s představou tzv. formatio ${ }^{8}$, tj. jakéhosi dvoudílného procesu, který nejdříve popisuje tvarování původní látky ${ }^{9}$ a její následné oživení. ${ }^{10}$

Je možná překvapivé, že Zlatý věk se udál pod patronací Kronovou (jež je líčen jako divoký bůh pojídající své děti). Homér a po něm Hesiodos jsou již básníky nového řádu - Diova. Pád lidstva je pak již samozřejmě spojen s Diem. Prométheus je líčen až k Aischylovi jako ten, který se o pád lidstva de facto zasloužil. ${ }^{11}$ Lidstvo je díky němu odsouzeno. Až Aischylos jej ve svém Spoutaném Prométheovi vidí jako jednoznačného nositele dějinného pokroku, jako toho, který lidem přináší poznání.

\section{b) Mythologicko-filosofický koncept "věčného návratu téhož ${ }^{\text {12 }}$}

Zřejmě archetypální koncept spjatý s většinou civilizací Středozemí, protože je vázán na přírodní cyklus, který ovládá zemědělský život tehdejších civilizací. Tento koncept vidíme coby součást kultu civilizací mezopotamského prostoru, Egypta aj. Rovněž Řekové se ve svém vnímání času/dění identifikují zcela logicky s tímto pojetím. I oni jsou národem zemědělským.

To, co je implicite součástí řecké každodennosti, explicite naplno vyjádří až řecká filosofie, jako první Anaximandros z Miletu ve svém známém Zlomku.

\footnotetext{
6 Hesiodos: Práce a dni, in Hesiodos Železný věk, Odeon 1976

$7 \quad$ Ani v jeho Theogonii nenajdeme vyprávění o stvoření člověka. Ani u Homéra toto vyprávění nenajdeme. Srovnáme-li bohatost starších duchovních tradic, jde možná o fakt zarážející. Jen sumersko-akkadská, resp. starobabylónská tradice má takových vyprávění několik. Řekové zřejmě nemají tyto tendence, jednoznačnou antropogonii u nich nenajdeme.

$8 \quad$ Vedle této "formující ${ }^{\prime \prime}$ představy najdeme v sumerských mýtech i představu označovanou jako EMMERSIO, kdy bůh Enlil zaseje a nechá lidstvo vyrůst jako obilí.

9 Podle pozdní řecké tradice (4.stol.př.n.l.) Prométheus uhnětl lidi z hlíny.

10 O sumerské tradici jsme se již zmínili. Bůh Enki (Ea) formuje materii, často božské povahy, a pak do ní vdechne život. Tato představa bezesporu ovlivnila ,jahvistu“ s jeho vyprávěním o stvoření člověka z prachu země (viz Gen 2.4.). Řecká představa vyslovená v Platónových podobenstvích je velmi podobná.

11 On je autorem první oběti, tj. pochybného dělení obětovaného dobytčete. Po dalším Prométheově úskoku (krádež ohně) pak Zeus sešle na lidstvo starost.
}

12 Volíme tento titul 
"Anaximandros prohlásil neomezené za počátek a základní proek jsoucna; proní zavedl toto jméno "počátek“. Říká pak, že to není ani voda, ani žádný $z$ tzv. Živlů, nýbrž jakási jiná neomezená přirozenost, $z$ níz vznikají všechny oblohy a světy $v$ nich. „A $z$ čeho věci vznikají, do toho téż zanikaji podle nutnosti, nebot si za své bezpráví navzájem platí pokutu a trest podle určení času“; takto to řiká slovy ponèkud básnickými... Nevykládá vznik věcí proměnou živlì, nýbrž tím, že se věčným pohybem vylučují protivy." 13

Za nejvýznamnějšího představitele cyklického pojetí času/dění je ovšem neodiskutovatelně pokládán Herakleitos z Efesu. Podobně jako Hesiodos a později Platón je i Herakleitos „zahleděn do minulosti“. To je dáno především jeho původem. Herakleitos je původem z královského rodu, je to aristokrat sledující zásadní společenské změny „svého“ Efesu, kde jsou aristokratické prvky postupně nahrazovány rodícími se momenty demokratickými, staré je nahrazováno novým. Stabilita starých poměrů je stř́idána chaosem novot. Mimo jiné i v těchto historickospolečenských motivech zřejmě můžeme hledat zdroje Herakleitovy děcí a relativistické filosofie.

Herakleitos je myslitelem permanentní změny. Jistým momentem této děcí filosofie pak je i jeho koncepce tzv. Velkého roku a ekpyrósis, které mají být potvrzením cyklického vnímání času/dějin. Právě tento koncept nás v souvislosti s naší tématisací zajímá.

Do výkladu vstupme konfrontací dvou tezí, které se jeví na první pohled jako kontradikce. "Tento svět, týž pro všechny, nestvořil žádný z bohủ ani z lidí, ale vždy byl, je a bude věčně živým ohněm, rozněcujícím se podle míry a hasnoucím podle míry." ${ }^{14} \mathrm{~V}$ tomto známém zlomku Herakleitos stručně řečeno říká: tento svět není stvořený, resp. je věčný, je permanentním děním, které má svůj řád (LOGOS), svou míru a věčně živý oheň (PYR AIEZOON) je pak ARCHE tohoto dění.

Naproti tomu zachovala celá řada doxografů teze, které zásadně popírají dikci zlomku právě uvedeného.

"Oheř, jenž prìjde, vše rozsoudí a uchváti.."15

"(svět) Vzniká z ohně a opět je spalován v určitých obdobích stř́davě po celý věk; děje se to podle sudby." ${ }^{16}$

"Herakleitos ř́ḱá, že se vše jednou stane ohněm." 17

13 Zl. A9 a B1 ze Simplikia, in Zlomky předsokratovských myslitelů

14 Zl. B30, in Zlomky předsokratovských myslitelů

15 Zl. B66 z uv. Spisu, in Zlomky předsokratovských myslitelů

16 Zl. A1 z Diogena., in Zlomky předsokratovských myslitelů Podíváme-li se přímo do Diogena, pak má teze tuto širší podobu: „Vesmír je konečný a svět je jen jeden; střídavě se rodí z ohně a zpět se opakuje v určitých obdobích po celou věčnost; děje se to podle osudového určení." (Diogenes Laertios, s. 24) 
"Podle Herakleita se skládá veliký rok z 10800 (tj. 30 x 360 let) slunečních let."18

"Herakleitos uznává za počátek všeho oheň, že podle něj jsou uhasináním ohně vytvářeny všechny věci, a že svět a všechna jsou ničena ohněm v (světovém) požáru."19

„Herakleitos uznává též jakýsi počátek a vymezený čas pro změnu podle usouzené nějaké nutnosti." 20

"Herakleitos řiká, že je svět střídavě stravován (EKPYRUSTHAI) ohněm a znovu z něj vzniká (a uskutečňuje se) po určitých časových obdobich." 21

Právě těchto sedm uvedených zlomků vedlo starověké doxografy a zejména potom stoiky, v době novější potom: F.D.E. Schleiermachera, F. Lasala, J. Burneta aj. ke konstatování, že Herakleitos je hlasatelem koncepce světového požáru²2 (EKPYRÓSIS dosl. vzplanutí, roznícení, shoření) a s ní související nauky o tzv. Velkém roku vymezeném světovými požáry opakujícími se periodicky každých 10.800 let. Právě perioda 10.800 let $(360$ dnů v roce násobeno 30 dny měsíce či 30 lety vymezujícími jednu lidskou generaci) vytváří cyklus světového života (dějin), v němž nastává „chvíle“, kdy je celý svět sežehnutí ohněm a vše hyne ve světovém požáru, aby se vše znovu obnovilo. Tento proces zkázy a následné obnovy je věčný.

Máme tu v každém případě dva závěry, jež si navzájem protiřečí a zatemňují jeho nauku. Nebudeme se pouštět do argumentace pro to či ono stanovisko (věcnost/stvořenost, resp. permanentní dění/plynutí vers. cykličnost), která trvá od starověku po současnost. Jedno je však zřejmé, Herakleitos nám zanechal svědectví, byt' sporné, o filosofickém uchopení něčeho, co bude po značnou část vývoje antické spirituality utvářet jistý postoj k otázce času, resp. dějin.

\section{Platón}

Je možná překvapivé, že ve své kritice historicismu v Otevřené společnosti a jejích nepřátelích spojuje Popper Platonovu koncepci (společnosti a) dějin právě s Herakleitem.

Oba myslitelé jsou pro něj kvitesencí doby či dobou uchopenou v myšlence (jak by řekl Hegel). Podobně jako Herakleitos z této reflexe vyvozuje podle Poppera i Platón, že „veškerá společenská změna je zkázou, rozkladem a degenerací.“23 Platón

\footnotetext{
17 Zl. A10 z Aristotela., in Fysiky III. 5

18 Zl. A13 z Aetia, in Zlomky předsokratovských myslitelů, resp. Censoria - gramatika z III. stol.n.l. (viz Diogenes L)

19 Zl. A5 z Aetia, in Diels-Kranz: Die Fragmente der Vorsokratiker, Weidmann 1951

20 Zl. A5 ze Simplikia, in Zlomky předsokratovských myslitelů

21 Zl. A10 ze Simplikia, in Diels-Kranz: Die Fragmente der Vorsokratiker, Weidmann 1951

22 Už ve starověku měl Herakleitos přezdívku SKOTEINOS (temný).

23 Popper: Otevřená společnost, s. 28
} 
má možná ještě více osobních důvodů k odsudku všeho, co přišlo, resp. odchýlilo se od ideálního stavu uspořádání věcí veřejných - tj. původní rodové aristokracie, k níž se Platón hlásí24. Doba nedávná i doba jeho současnosti mu totiž předkládá de facto všechny druhy po aristokracii následujících ústav. Je svědkem střídání aristokracií, nová - obchodní a peněžní - mu střídá starou rodovou, má svou zkušenost s athénskou demokracií, jež se podepisuje pod ortel jeho učitele, vláda třiceti tyranů po prohrané válce se Spartou (které se mj. aktivně zúčastnili Platónovi příbuzní: Krritias a Charmides). Cesta na Sicílii pak znamenala osobní zkušenost s dalším tyranem Dionysiosem St. Tedy timokracie/oligarchie, demokracie i tyranie jsou Platónem zažity, doslova. Kritickou reflexi nám podává VIII. kniha Ústavy. Doplnit si tyto osobní zkušenosti do matrice hesiodovské koncepce nebylo tedy nic nelogického. Platón se často odvolává na "zlatý věk“, kdy lidskému pokolení vládl Kronos, jako na stav ideální. ${ }^{25}$

Takže rovněž on je představitelem, což také v Ústavě explicite říká, té dějinné představy, jež chápe dějiny jako sestup.

In concreto nám v již vzpomínané VIII. knize Ústavy předkládá reflexi tohoto dějinného sestupu. Zlatý věk, tj. aristokratické26 zř́zení je dávná minulost, to, co následuje timokracie/oligarchie ${ }^{27}$, demokracie ${ }^{28}$ a konečně tyranis. Železný věk, tot' současnost. Jinou otázkou je odpovídá-li tento Platónův scénář historické realitě Athén posledních století, kde bychom mohli v mnohém s Platónem polemizovat např. $\mathrm{v}$ otázce historické role tyranidy (např. pokrokové role athénských tyranů $\mathrm{v}$ čele s Peisistratosem), „čistotě“ tehdejší athénské demokracie apod.

Společenskou realitou zklamaný aristokrat Platón před sebou vidí hesiodovský scénář.

Je-li tomu však tak, jak jsme posud konstatovali, proč nám Platón předkládá svůj velkolepý do nejrůznějších detailů propracovaný koncept uspořádání obce neníli cesty zpět, jsou-li dějiny permanentním sestupem.

Zde do Platónova uvažování vstupuje druhý motiv, který nakonec spoluvytváří celkovou dějinnou komposici. Tradiční motiv cyklu, resp. cyklického vnímání dějin, který je v návaznosti na starší mythologické tradice obráběn zejména

\footnotetext{
${ }^{24} \mathrm{Z}$ otcovi strany je Platón představitelem dlouhé rodové tradice sahající až k poslednímu attickému rodovému králi Kodrovi. $Z$ matčiny strany pak linie směřuje $\mathrm{k}$ Solonovi.

25 Zmínky najdeme jak v Ústavě, tak Politiku (272 C, D) a Zákonech (IV, 713A).

26 Aristokracie - dosl. vláda nejlepších (od KRATO, EIN - vládnu, vládnouti; ARISTUO, EIN vynikám, vynikati).

27 Timokracie dosl. vláda ctižádostivých (TIMEI - čest, pocta, ctižádost), oligarchie dosl. vláda několika (OLIGOS - málokterý, nečetný), zpravidla několika majetných, tyranie dosl. vláda samovládce, násilná vláda (TYRANNUO, EIN - násilně vládnout)

28 Demokracie dosl. vláda lidu (DEMOS - lid), pro Platóna spíše vláda lůzy.
} 
předsokratovským př́rodním filosofováním, přináší de facto Platónovi naději a osmysluje důvody jeho vise. M. Eliade k tomu říká:

„Vidime, že ve všech kosmicko-mythologických lunárních koncepcích dominuje cyklický návrat toho, co bylo dřive, jedním slovem "věčný návrat". Také zde se setkáváme s motivem opakování archetypového gesta, přeneseného do všech rovin: kosmické, biologické, historické, lidské atd. Současně však odhalujeme cyklickou strukturu času, který se regeneruje při každém novém "zrozeni" v kterékoli rovině. Tento "věčný návrat" svědčí o ontologii, do níž nezasahuje čas ani dění. Stejně jako Řekové v mýtu o věčném návratu ukájeli svou metafyzickou touhu po "ontologickém“ a statickém (poněvadž z hlediska nekonečna vývoj věci, které se ustavičně vracejí do téhož stavu, je tím implicitně anulován, a dokonce se dá tvrdit, že "svět zůstává nehybný"), podobně i "primitiv" anuluje nezvratnost času tím, že mu přisuzuje cyklický průběh. Všechno začíná v každém okamžiku znovu od svého začátku. Minulost je jen prefigurací budoucnosti. Žádná událost není nezvratná a žádná změna není konečná. Lze i ř́ci, že v jistém smyslu se na světě neděje nic nového, protože všechno je jen opakování týchž prootních archetypů. Toto opakování aktualizací mytického okamžiku, kdy bylo archetypové gesto zjeveno, udržuje svět bez ustánív témž jitřním okamžiku počátku. Čas pouze věcem umožňuje, aby se objevily a existovaly. Na tuto existenci však nemá žádný rozhodující vliv - protože se neustále regeneruje."

Platón explicite nikde nehovoří o cykličnosti dějin. To, že s tímto motivem „počítá“, lze podle Poppera dedukovat pouze z narážek. Nejčastěji naráží Platón na (Herakleitovskou) koncepci Velkého roku. ${ }^{29}$ Popper uvádí čtyři místa, kde se Platón zmiňuje o Velkém roku, resp. cyklu: ve Faidonu (70 E - 72 B), v Ústavě (kn. VIII. a IX.) a asi nejvýmluvněji v Politiku (268 E - 274 E). U tohoto se zastavme podrobněji. Platón zde hovoří o tom, že tento svět je řízen v polovině svého cyklu bohem. Tento „pưlcyklus“ je postupem vpřed, je postupem rozvoje nijak nezkalený bojem a svárem ${ }^{30}$. V druhém půlcyklu pak bůh otěže pouští z rukou, nastává období úpadku. $\mathrm{V}$ tomto období de facto žijeme. Nakonec situace dospěje k bodu, kdy se Bůh opět chopí otěží, a tak zachrání svět před úplným zničením. Jestliže Faidon a Ústava jsou spíše projekcí nauky antropologické, tj. pádu a návratu duše „domů“ (explicitně zpracováno ve Faidru). Návrh Ústavy je projekcí Platónovy antropologie.

Politikos nese však rovněž jisté prvky kosmologické. ${ }^{31} \mathrm{~V}$ podobném duchu se nese poslední významnější zmínka v Zákonech (76 B - 677 B) ${ }^{32}$. Drobné narážky na motiv cyklu najdeme i na jiných místech (např. v Timaiovi). Svým zpơsobem se dá

\footnotetext{
29 Trvání Velkého roku je 36 tisíc let.

30 Zde Platón zřejmě naráží na Empedokla z Akragantu, jehož nauka vykazuje některé př́ibuzné rysy s Herakleitovou.

31 S tím samozřejmě souvisí Platónův poukaz na Zlatý věk, o kterém jsme se zmínili již výše.

32 Rovněž zde Platón poukazuje na Zlatý věk.
} 
říci, že právě Platonova společenská koncepce je nejprůkaznějším dokladem Platónova přitakání cykličnosti.

\section{Poplatónská tradice - stoa}

Stoicismus je bezesporu nejvlivnějším směrem II. období antické filosofie, resp. filosofie hellenistické33. Své postavení víceméně obhájil i v období III. (tj. od přelomu letopočtu k $1 / 23$. stol.). Svého vrcholu však dosahuje v druhém období antického filosofování, kdy na filosofickou scénu vystupují postupně rozhodující postavy stoicismu: Zenón z Kitia, Chrysippos ze Soloi, Pananaitinaitos z Rhodu a Poseidonios z Apameie. Jen jediný z výše jmenovaných nezastává tradiční údajně stoický koncept herakleitovského původu: Velký rok ohraničený světovými požáry ${ }^{34}$, totiž Panaitinaitos.

Nejhojnější zmínky o daném tématu se nám zachovaly u "pilíře stoy“35 Chrysippa. Zlomky starých stoiků shromážděné von Arminem obsahují k našemu tématu následující fragmenty ${ }^{36}$ : vytoára... ${ }^{37}$

...Ďalej vraví, že v osudovo určených obdobiach sa celý svet striedavo spaluje a opat'

Nesúhlasí azda s Panaitiom, Chrysippom a Zenonom ten, kto sa svetu vyhráža ohňom a vraví, že príde čas, ked' zhorí?38

Podl'a stoikov svet je zničitel'ný, a to vzplanutím. ${ }^{39}$

Platon vravi, že svet vznikol, ale nezanikne. Iné vravia stoici a epikurovci, tordiac, že aj vznikol, aj zanikne. ${ }^{40}$

Stoici hlásajú, že svet je zničitel'ný, pretože bol stvorený, a odovodňujú to analogicky podl'a vecí, ktoré sa uchopujú zmyslovým vnimaním; ak časti niečeho podliehajú zničeniu, je zničitel'ný aj celok; a časti světa sú zničitel'né, kedže sa premieňajú jedny na druhé: teda svet je zničitel'ný. Ďalej ak niečo pripúšt́a zmenu na horšie, je zničitel'né, a teda aj svet, kedža sa vysúša a zase mení na vodu. ${ }^{41}$

33 Hellenistickou dobou označujeme dobu od smrti Alexandrovy v r. 323 př.n.l. až do r. 31 př.n.l. kdy Octavianus poráží u Aktia Marka Antonia.

$34 \quad$ V hellenistickém období se myšlenka světového požáru obnovujícím svět objevuje v íránském náboženství, zejména v tzv. eschatologické literatuře (Bahmán Jaštu, Hystapova věštba aj.).

35 Cicero

36 Žel, čerpáme ze slovenského výtahu, který je obsahově as čtvrtinový vưči von Arminově sbírce. I tak bude uvedené snad dostatečně ilustrativní.

${ }^{37}$ Eusebius, Praeparatio evangelica, XV p. 816D, in Zlomky starych stoikov

38 Arnobius, Ad nationes, II g, in Zlomky starych stoikov

39 Aetius, II 4, 7, in Zlomky starych stoikov

40 Comenta Lucani, VII 1p. 220 Us., in Zlomky starych stoikov

41 Diogenes Laertius, VII 141, in Zlomky starych stoikov 
Hviezdy sú ohnivej povahy; živia sa výparmi země, mora a vod, ktoré slnko vysáva zo zohriatych polí a vod. Nimi posilnené a osviežené hoiezdy aj celý éter ich vracajú naspat' a potom opat' vpijajú do seba, takže takmer nič z nich nehynie, alebo len málo, čo pohltí oheň hviezd a plameň slnka. Z toho naši učitelia uzatvárajú, že nakoniec celý svet zhorí, ked' sa spotrebuje všetka vlhkost' a ani zem sa nebude mat' čím živit', ani vzduch sa po vyčerpaní všetkej vody nebude moct' obnovit', a tak neostane nič okrem ohňa. No potom tento oživujúci oheň, boh, začne znovu obnovovat' svet a uvádzat' ho do takého istého súladu. ${ }^{42}$

Kto z múdrych pochybuje, kto nevie, že všetko, čo vzniklo, hynie, a všetko, čo bolo vytvorené, zaniká? Aj nebo so všetkým, čo obsahuje, tak jako začalo, premení sa na oheň, ked' sladká voda prameňov prestane živit' moria. Stoici s rozhodnostou tordia, že po spotrebovaní vlhkosti sa celý svet premení na oheň. 43

Stoici sa nazdávajú, že svet vzplanie a očistí sa, a to pod'la jedných cele, pod'la druhých sčasti. Vravia, že sa takto po časti očistuje; zánik a opatovný vznik světa nazývajú očistením. ${ }^{44}$

Stoici vravia, že ked' silnejši element zvítazí nad ostatnými, svet vzplanie a všetko sa premení na oheň. 45

$V$ 1. knihe O prezretel'nosti píše, že Zeus (oheň) bude rást', až kým všetko nepohltí: „Smrt' je oddelenie duše od tela, no duša světa sa neoddel'uje od neho, ale ustavične rastie, až kým nepohltí látku, a teda nemožno povedat', že svet umiera." Svet je vraj sebestačný, pretože má v sebe všetko, čo potrebuje, živí sa a rastie zo seba samého, zatial čo jeho časti sa navzájom menia. ${ }^{46}$

Podl'a stoikov jestvuje prázdny priestor, do ktorého, kedže je nekonečný, sa svet po vzplanutí rozloži. $\quad 47$

Lepšie to vykládá Chrysippos, o ktorom Cicero hovorí, že je sl’pom stoikov. V knihách O prozretel'nosti, ked' vravel o obnovení světa, povedal toto: "Ked' je to tak (totiž že svet zhorí), je jasné, že nie je nijako nemožné, aby sme sa aj my po smrti v istých časových intervaloch neobjevili na svete $v$ našej terajšej podobe. ${ }^{48}$

Aj Herakleitos pozná toto očistenie (zlých l'udí) ohňom, ktoré neskorší stoici nazvali vzplanutím a učili, že prostredníctvom neho povstaneme zase takí istí. ${ }^{49}$

Nikto z l'udí neumrie viac ráz, jako sa odvážil napisat' Origenes, chcejúc autoritou Svatého písma potvrdit' najnehanebnejšie učenie stoikov. 50

Cicero, De natura deorum, II 46, 118, in Zlomky starych stoikov 
Vraví sa, že Diogenes sa v mladosti pridal k učeniu o ekpyróze, no v neskoršom veku od neho upustil. ${ }^{51}$

Podl'a Herakleita sa vel'ký rok skladal z 18000 slnečných rokov. Podl'a stoika Diogena mal 365-krát tol'ko rokov jako rok podl'a Herakleita. 52

Doktrína Velkého roku tak, jak byla přijata stoiky (a nejen jimi), byla ve 3. stol. př.n.l. coby původně chaldejská rozšířena pro hellenistický svět zpopularizována Beróssem. Římané a Byzanc ji $\mathrm{v}$ této podobě později rovněž přijali. Podle této předlohy je vesmír věčný, ale je periodicky ničen a následně obnovován každý Velký rok světovým požárem. ${ }^{53}$

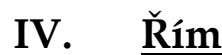

Podíváme-li se na duchovní situaci 1. stol. př.n.l., resp. přelomu letopočtu, tedy situaci dynamické proměny tehdejšího římského světa z hlediska duchovní pestrosti, pak zde najdeme velmi rozmanitou škálu různých filosofických a náboženských proudů. Z hlediska námi sledované problematiky, pak bude zajímavé sledovat, pomineme-li rozšířenou apokalyptickou představu orientálního původu ohlašující blížící se konec římské moci (tzv. Sibyllininy věštby), tři dějinné představy tradiční:

a) stará římská představa o konci Říma vyplývající z mýtu o dvanácti supech oznamující délku trvání „věčného města“;

b) stoická představa tzv. Velkého roku;

c) hesiodovská (ovidiovská) koncepce pěti (čtyř) věků;

d) všechny jmenované představy se spojily de facto v jeden koncept, zároveň však nástupem Augustovým k moci (r. 27) se tento pesimistický trojjediný koncept v „rukou“ Vergiliových částečně eliminuje, resp. modifikuje.

Doba obou triumvirátů, doba permanentní občanské války byla chápána současníky jako naplňování pesimistické představy konce. Překročení Rubikonu Caesarem (r. 49) bylo interpretováno novopythagorejcem Negediem Figulusem jako počátek „apokalypsy“ konce Říma. Podívejme se nyní na výše zmíněné komponenty vzpomenutého pesimistického obrazu. 
ad a) Dle pověsti viděl Romulus při zakládání města vylétat 12 supů ${ }^{54}$, kteří byli znamením počtu let jeho trvání. Toto mystické číslo implikovalo děsivé představy současníků o konci Říma. Ale po 120 letech se předpověd' nenaplnila, nenaplnilo se ani očekávání jednoho "Velkého roku“, tj. 12 x 10 měsíců (365let). Zdálo se, že tím pravým výpočtem pak asi bude „Velký rok“ složený z dvanácti měsíců o stu letech.

Na první pohled je tato představa lineární, Řím má svůj začátek 753/754 a rovněž předpokládaný konec. Na straně druhé je však „Velký rok“ chápán jako vyjádření cyklu.

Dříve než přistoupíme $\mathrm{k}$ vergiliovské modifikaci, seznámíme se $\mathrm{s}$ dalšími komponenty.

ad b) Stoická koncepce „Velkého roku“ a ekpyrose. Již výše jsme zmínili, že rozhodující vliv na římskou akceptaci stoicismu měl zřejmě Poseidonios, případně jeho žáci55. Poseidonios uznává stoickou nauku Velkého roku a rovněž koncepci Zlatého věku lidstva, od kterého se lidstvo postupně vzdaluje. Na druhé straně je třeba říci, že Poseidonios rovněž navazuje na demokritovskou koncepci lidského pokroku, která ovšem vede $\mathrm{v}$ konečném $\mathrm{k}$ úpadku mravů. ${ }^{56}$

Výše jsme se zmínili o tom, že stoicismus zřejmě čerpá z chaldejských tradic a samozřejmě z řecké tradice (resp. z Řeky zpracované chaldejské doktríny). Tzv. Velký rok, jenž je posléze různě počítán, začíná v okamžiku, kdy se spojí všech sedm planet ve znamení Raka (zimní slunovrat, tzv. Velká zima), v okamžiku kdy se spojí ve znamení Kozoroha - letní slunovrat přichází vesmírný požár. 57

Kosmologickou fundaci má Velký rok rovněž v římské interpretaci. Římané spojují ekpyrósis se stoletím Slunce. Vergilius nahradil století Slunce stoletím Apollóna.

ad c) Públis Ovidius Nasó (+18 n.l.), básník zlaté doby řecké poesie, která se kryje se Zlatým věkem Augustovým, nám ve svých Proměnách (Metamorphoses), do nichž zakomponovává celou řadu motivů řecké a římské mytologie, předkládá rovněž převyprávěnou verzi hesiodovského vyprávění o střídě věků lidstva:

„Zlatý vzešel nejprve věk, kdy zákona, soudce

\footnotetext{
54 Romulus a Remus se nemohli domluvit na jménu zakládaného města. Domluvili se tedy na tom, že město ponese jméno podle toho $\mathrm{z}$ nich, který (a $\mathrm{v}$ tom se objevil kámen úrazu) z nich uvidí dříve nebo více letících ptáků. Remus z Aventina uviděl nejdřive 6 supů, Romulus z Palatina 12 supů. Vznikl spor, jenž vyústil v Removu smrt. Odtud mystické číslo 12.

$55 \quad$ K nejvýznamnějším představitelů římského stoicismu sledovaného období patřili: Athenodros z Tarsu, Hekaton a Didotos.

$56 \quad$ Poseidonios je jakýmsi antickým Rousseauem.

57 Eliade ř́ká, že tyto představy ovlivněné zřejmě Babylonem najdeme v Indii, v Iranu aj.
} 
člověk byl prost a od sebe sám ctil věrnost a právo.

Nebylo trestu ni strachu, a hrozivá slova se nečtla, vyrytá v kov, a prosící dav se nemusel báti soudcových úst: ač neměli obhájce, bezpečni byli. Nebyla skácena dosud a nesešla do plynných proudi̊ pínie se soých hor, chtíc daleké navštívit kraje: neznali jiného břehu krom vlastního smrtelní lidé. Srázný hluboký př́kop až doposud nevroubil města, nebylo stočených rohů, ni polnice z rovného kovu, nebylo mečù ni prílb: svůj život trávilo lidstvo bezpečně v lahodném klidu, a vojska mu nebylo třeba. Od sebe sama vše též jim dávala svobodná země: ještě se netkl jí rýč, a pluh jí nezranil dosud; člověk, spokojen jídlem, jež poskytla příroda sama, planik plody si sbíral a trávnice rostoucí v horách, dřínky a ostružin plody, jež visely v trnitém křoví, žaludy též, jež na zem spadaly s Jovova stromu. Věčné bývalo jaro, a lahodných Zefyrů vlažné vánky laskaly květy, jež vyrostly beze všech semen. Brzy též zem, ač nikdo ji nevzdělal, plodiny nesla: klasy tu těžkými bělal se lán, ač preorán nebyl. Tu proud mléka, tam nektaru proud se potokem valil, onde zas zelený dub byl smáčen kapkami medu. Jakmile Sáturnus však byl do temnot Tartaru vyhnán, Júpiter ovládl svět, a stříbrné potomstvo vzešlo, horší zlatého sic, leč cennější plavého bronzu. Trvání bývalé vesny bůh Júpiter zkrátil a kázal, aby měl rok vždy po čtyřech obdobích v budoucnim čase, zimu, kratičké jaro, a léto a nestálou jeseň.

Tehdáž po proé vzduch se rozžhavil, sálaje žárem suchým, a ve výši uvízl led, jenž utuhnul větrem. 
Tehdáž po proé v obydlí vešli: jim obydlím byla jeskyně, křoviska hustá a proutí, svázané lýkem. Tehdáž do dlouhých brázd si po prvé obilná zrna zaseli; smutně pak zabučel býk, jsa obtížen jařmem. Třetí po tomto věk pak nastoupil, bronzové plémě, krutější povahou svou a $k$ strašným náchylné zbraním, přec však zločinu prosté. Pak z tordého železa - čtvrté Ihned vtrhl v ten věk, jenžz nejhorší rudy byl stvořen, veškeren hřích, a stud a pravda i poctivost prchla, na jeijich místo pak nastoupil klam a podvod a šalba, násilí, úklady, lest a zločinná k majetku láska.

Plachty svěřoval větrưm, ač dobř jich doposud neznal, plavec, a lodní kýl, jenž na horách vysokých dř́ve stával, v neznámých proudech vln se zahoupal skočně. Půdu, společnou dřív jak vzduch a sluneční světlo, všechnu presný měřič už vymezil hranicí dlouhou. Ne však obilí jen a povinné krmě si člověk od půdy bohaté žádal: on pronikl do útrob země, z ich pak kopat se jal též poklady, které kdys ona ukryla v hloub až k Stínům podsvětním, draždidla hříchu. Ocel již zločinná vzešla, a zločinnější než ocel zlato, vzešla i válka, jež bojuje obojím kovem: řinčící zbraň má v krvavých rukou a prudce jí mává. Žije se z loupeže ted': tchán před zetěm, před hostitelem host už není si jist; i bratrská láska je vzácná; číhá chot', jak zahubit manželku, manželka chotě; jedů smrtelnou bledost zas ukrutné macechy mísí po délce života otcova syn se předčasně pídí. Zbožnost je svalena v prach a zdolána. Poslední z bohů 
se země, nasáklé krví, se vzdálila panenská Diké." 58

Ovidius nám předkládá částečně pozměněnou versi Hesiodovu, vynechává ve svém sledu věk heroů. I zde můžeme číst apoteózu Zlatého věku a kritiku současného - železného.

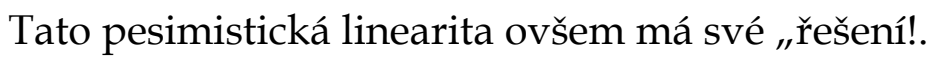

ad d) Podobně jako Platón rovněž římská spiritualita výše zmíněné koncepty spojuje. Vládnoucím principem je určitě princip cyklu, resp. Velkého roku. To je základní dějinná perioda. Sám běh tohoto cyklu kopíruje de facto postupnou střídu věků, každý cyklus začíná věkem zlatým a končí železným. Pak ekpyrósis „vše uchvátí“ a z popela vzejde nový zlatý věk, jenž zahájí nový cyklus.

Zmíněné občanské války provázející Řím až do nástupu Octavianova byly reflektovány jako apokalyptická předzvěst konce tohoto věku a celého cyklu.

Ovšem nestalo se tak a dějinná perspektiva se zásadně proměnila. Další z velikánů tehdejší zlaté doby římské poesie Publius Vergilius Maro (+19 př.n.l.) ve své IV. ekloze Zpěvů pastýřských (Bucolica) přichází s myšlenkou, že Zlatý věk přijde za konsulátu Asinia Polliona (40 přn.1.), tj. před vítězstvím Octaviana. Píše o novém cyklu věků a návratu vlády Saturna- Krona (Zlatého věku). Jak jsme již řekli výše, v Aeneidě přichází s tím, že Zlatý věk již začal, století Slunce, které coby př́činy ekpyrose, nahradil stoletím Apollona. Občanské války pochopil jako vlastní přechod k Zlatému věku. Augustus již garantuje nastoupivší Zlatý věk, věčný mír, Řím se může periodicky ad infinitum regenerovat.

\section{V. Židovsko-křest'anské pojetí dějin}

Od 1. stol.n.l. vstupuje na dějinnou scénu nový fenomén, nová spiritualita, která postupně de facto a posléze de iure ovládne Řím a celou antickou scénu vůbec: křestáanství.

Ve svém pojetí dějin naváže zejména na židovskou spiritualitu. Židé jsou zřejmě prvním národem/kulturou nového vnímání času/dějin.

Tento koncept ač historicky náležející ještě antice, duchovně je již záležitostí nového světonázoru, a proto se tomuto fenoménu budeme věnovat podrobněji $\mathrm{v}$ některé další studii. 


\section{Bibliografie}

Zlomky předsokratovských myslitelů, Praha 1962

Zlomky starých stoikov, Bratislava 1983

Hesiodos: Železný věk, Praha 1976

Ovidius: Proměny, Praha 1942

Platón: Ústava, Praha 1921

Politikos, Praha 1934

Zákony, Praha 1961

F.Ch.Kessidi: Herakleitos, Praha 1985

V. Špaňár: “Herakleitos z Efesu, Bratislava 1985

Rist: Stoická filosofie, Praha 1998

K.R.Popper: Otevřená společnost a její nepřátelé, Praha 1994

M. Eliade: Mýtus o věčném návratu, Praha 2003

Dějiny náboženského myšlení II., Praha 1996

V.F. Asmus: Antická filosofie, Praha 1986

A. A. Long: Hellénistická filosofie, Praha 2003

Diels H. - Kranz W.: Die Fragmente der Vorsokratiker, Dublin/Zurich 1971

M. Vlček: Přehled antické filosofie 2., Praha 2000

Marcus Aurelius Antonius: Hovory k sobě, Praha 1975

Díogenés Laertios: Životy, názory a výroky proslulých filosofů, Pelhřimov 1995

Vlček, Vacura: Vybrané texty z politické filosofie 1., Praha 2008. 


\section{E-LOGOS}

ELECTRONIC JOURNAL FOR PHILOSOPHY

Ročník/Year: 2010 (vychází průběžně/ published continuously)

Místo vydání/Place of edition: Praha

ISSN 1211-0442

Vydává/Publisher:

Vysoká škola ekonomická v Praze / University of Economics, Prague

nám. W. Churchilla 4

Czech Republic

13067 Praha 3

IČ: 61384399

Web: http://e-logos.vse.cz

Redakce a technické informace/Editorial staff and technical information:

Miroslav Vacura

vacuram@vse.cz

Redakční rada/Board of editors:

Ladislav Benyovszky (FHS UK Praha, Czech Republic)

Ivan Blecha (FF UP Olomouc, Czech Republic)

Martin Hemelík (VŠP Jihlava, Czech Republic)

Angelo Marocco (Pontifical Athenaeum Regina Apostolorum, Rome, Italy)

Jozef Kelemen (FPF SU Opava, Czech Republic)

Daniel Kroupa (ZU Plzeň, Czech Republic)

Vladimír Kvasnička (FITT STU Bratislava, Slovak Republic)

Jaroslav Novotný (FHS UK Praha, Czech Republic)

Jakub Novotný (VŠP Jihlava, Czech Republic)

Ján Pavlík (editor-in-chief) (VŠE Praha, Czech Republic)

Karel Pstružina (VŠE Praha, Czech Republic)

Miroslav Vacura (executive editor) (VŠE Praha, Czech Republic) 